\title{
Characterization of Nigerian Bitumen Extract Fractions
}

\author{
Alhassan $\mathbf{M}^{1 *}$, Asmau $\mathrm{MS}^{1}$, Nasiru $\mathrm{Y}^{1}$, Suleiman $\mathbf{M}^{1}$, Safiya $\mathrm{MA}^{1}$, Isah $\mathrm{AA}^{2}$, \\ Abdullahi B ${ }^{3}$, Garba $\mathbf{A A}^{1}$ and Kasimu $\mathbf{A}^{1}$ \\ ${ }^{1}$ Department of Chemistry, Sokoto State University, Nigeria \\ ${ }^{2}$ Department of Pure and Applied Chemistry, Usmanu Danfodiyo University, Nigeria \\ ${ }^{3}$ Chemistry Unit, Remedial and Basic Studies, School of General Studies (SGS), Federal \\ Polytechnic Kaura Namoda, Zamfara State, Nigeria
}

\section{Research Article \\ Volume 4 Issue 6}

Received Date: September 30, 2020

Published Date: October 13, 2020

DOI: $10.23880 /$ jenr-16000216

*Corresponding author: Alhassan M, Department of Chemistry, Sokoto State University, PMB 2134-Birnin Kebbi Road, SokotoNigeria, Email: mansuralhassan@gmail.com

\section{Abstract}

A comparative study was carried out to determine the behavior of N-hexane, Diethyether and Methanol extracts of Nigerian bitumen obtained from Irele Community of Ondo State, Nigeria. Total sulphate, Nitrogen and Moisture content were determined for the three extracts. FTIR, XRF techniques were employed to characterize the raw bitumen while GCMS was used to analyse the extracts. Moisture and Nitrogen content determinations revealed that diethylether extract has higher moisture (1.3\%) and Nitrogen $(0.854 \%)$; N-hexane extract has $1.0 \%$ and $0.784 \%$ while methanol extract is not detected (ND) and 0.084 moisture and Nitrogen contents respectively. SO3 (13.74\%), $\mathrm{CaO}(12.34 \%)$ and $\mathrm{Fe} 2 \mathrm{O} 3(7.33 \%)$ are the dominant oxides shown by the XRF spectroscopy with trace quantities of many impurities amounting to $58.68 \%$.

The total sulphate content of diethyether, $n$-hexane and methanol extracts was $0.70,0.62$ and $0.12 \%$ respectively. The Nigerian Bitumen compares favourably with other bitumen deposits, however, a lot of attention and resource is needed for its commercialization.

Keywords: Bitumen; Nitrogen Content; Moisture; Total Sulphate; Oxide Composition

\section{Introduction}

Bitumen is a sticky, black and highly viscous liquid or semiliquid form of petroleum. It may be found in natural deposits or may be refined product; it is a substance classed as a pitch [1,2]. Its viscosity ranges between 8 and $10 \mathrm{API}$ degrees. Its density $(\mathrm{kg} / \mathrm{m} 3)$ lies between 1.0 and 1.18 , insoluble in water, has a boiling point greater than $300^{\circ} \mathrm{C}$ with melting point ranging from $54-173^{\circ} \mathrm{C}$ and flash point greater than $200^{\circ} \mathrm{C}$.

Bitumen manufactured from crude oil is obtained as the last residue in fractional distillation of crude petroleum. The heavy residue obtained from the fractional distillation process is further treated and blended to make different grades of paving grade bitumen [3,4]. Processed bitumen plays an important role in many everyday applications. It is one of the most used solid mineral resources said to be useful in roofing, environmental protection, pipe coating, land slip containment, walkways, sound-proofing, electrical insulation, cosmetics, medicine and textiles. Bitumen's waterproofing and adhesive properties, durability and resistance to heavy loads make it the ideal material for use in all-weather environments. It is also a prime material in applications where strength and weather proofing are essential requirements. Moreover, bitumen membranes are extensively used as sound-deny panels in the automobile markets. It is also used as bituminous paints and disinfectants on a number of different surfaces, bitumen-based lubricants, preservative to plastic, sealants, and as asphalt for road construction and maintenance [5-7].

Christina [8], and Guma, et al. [9], Nigeria has an estimated bitumen (and heavy oil) reserves of about 38 and 14.86 billion barrels and ranked $6^{\text {th }}$ (in a list of top 10 countries) with bitumen and heavy oil reserves succeeded 


\section{Journal of Ecology and Natural Resources}

by Madagascar,UK, China and Azerbaijan with Canada, Venezuela, Kazakhstan, Russia and USA taking the lead. Francis [10], reported that Nigeria has an extrapolated reserve of 42 billion barrels and ranked second largest country with bitumen reserves, after Venezuela. Bitumen can be converted to liquid and refined to produce commercial products like gasoline, fuel oil and asphalt.

Ondo State is the most noted area of bitumen activities in the belt and has offices of Nigerian Bitumen Development Project located at Akure and Ore. Generally, some distinct bitumen-impregnated hydrocarbon types of occurrence have been identified within the Nigerian bitumen belt from topsoil downwards and location to location as: Outcrop, rich sands, lean sands, shales and heavy crudes. The average bitumen content of Nigerian tar sand is about $20 \%$ by weight. Very rich natural bitumen deposits are found in Ondo State around the region of Idiobilayo, Foriku, Agbabu, Okitipupa, and Aiyibi. Generally, tar sands are composed of bitumen, water and some mineral impurities. Tar sands with $5-10 \%$ by weight bitumen content are designated as good or medium grade [9-11].

According to Christina [8], Adedinila [11]; as well as Adebiyi and Akhigbe [12], the natural bitumen deposits of Ondo State are found in two basic forms, namely; soft and low viscosity /plain bitumen and outcrops of bitumenimpregnated sands extracted either by small-scale surface mining, large-scale surface mining and in-situ extraction.

\section{Experimental}

\section{Materials}

\section{Sample Procurement, Preparation and Pretreatment}

N-hexane, Diethylether, Methanol were purchased from a scientific shop in Sokoto State and stored without further treatment. Raw bitumen sample was obtained from Irele Community of Ondo State, Nigeria and preserved in plastic container till further use.

\section{Preparation of Bitumen Extracts}

The Extraction method adopted was Solvent extraction method using N-hexane, Diethyl ether and Methanol solvents. Fifty $(50 \mathrm{~g})$ of the bitumen sample was transferred into a thimble and placed in the Soxhlet extractor fixed with boiling flask, filled to three quarter (3/4) with N-hexane. The same was used for Diethyl ether and Methanol solvents. Continuous extraction was done until a $1 \mathrm{~h}$ contact time was reached. The three (N-hexane, Diethyl ether and Methanol) extracts collected in separate glass containers.

\section{Analyses of Extracts}

Total sulphate content as determined by
Spectrophotometry method (Turbidometric and Colorimetric Method) described by Subramanian M, AOAC [13] and Nitrogen content by Kjeldhal method [14].

\section{Nitrogen Concentration (Kjeldhal Method)}

The method described by Krebs RD [14] was adopted for the Nitrogen content determination. One gram $(1 \mathrm{~g})$ of the sample was weighed into $250 \mathrm{ml}$ kjeldhal flask. One tablet of kjeldhal catalyst was added followed by $10 \mathrm{ml}$ of concentrated $\mathrm{H}_{2} \mathrm{SO}_{4}$. It was heated gently for 15 minutes and rapidly at high temperature of $35^{\circ} \mathrm{C}$ until a clear or light green or grey colour was observed. The solution was allowed to cool and diluted to $100 \mathrm{ml}$ with distilled water. $5 \mathrm{ml}$ of $2 \%$ boric acid was put into $100 \mathrm{ml}$ beaker. 2 to 3 drops of mixed indicator were added and put at the tip of the condenser which has been fixed with the Markham distiller. $5 \mathrm{ml}$ of the diluted digest was put into the Markham, followed by $10 \mathrm{ml}$ of $40 \% \mathrm{NaOH}$ and the tap closed. It was steam distilled until $50 \mathrm{ml}$ of the distillate was recovered in the beaker at the tip of the condenser. The distillate was then titrated with $0.01 \mathrm{M}$ $\mathrm{HCl}$ until the colour changed to give the end point. The same process was carried out with the blank (distilled water used for dilution).

\section{Total Sulphate Concentration (Turbidometric Method)}

Turbidometric method described by Subramanian M, AOAC [13] was adopted to determine the total sulphate concentration. The sample was digested $2 \mathrm{gm}$ of it into a Kjeldahl flask. At pH 3.0, $5 \mathrm{ml}$ of concentrated $\mathrm{HNO}_{3}$ was added and evaporated. $10 \mathrm{ml}$ of $70 \% \mathrm{HClO}_{4}$ was added with few boiling ships. It was heated strongly until a clear solution was observed. $6 \mathrm{M} \mathrm{NaOH}$ was added to neutralize it. It was made up to $100 \mathrm{ml}$ with distilled water in volumetric flask. $5 \mathrm{ml}$ of conditioning reagent $50 \mathrm{ml}$ glycerol, $30 \mathrm{ml}$ concentrated $\mathrm{HCl}, 300 \mathrm{ml}$ distilled water, $100 \mathrm{ml} 95 \%$ ethanol and $75 \mathrm{~g}$ $\mathrm{NaCl}$ ) was added. On stirring, a spoonful of Barium chloride crystal was added and stirred constantly for one minute. It was poured into the absorbance cell and the absorbance of the turbidity produced was taken by UV Spectrophotometer at $425 \mathrm{~nm}$. Absorbance of the Blank and serial dilution of primary standard sulphates stock solution were obtained at the same temperature.

\section{Characterization}

The XRF spectrum was obtained using Xenemetrix $\mathrm{X}$-Cite multi-element spectroscopic bench top analyzer The elemental composition was developed using Horizon $\mathrm{MB}^{\circledR}$ XRF software. GC-MS was carried out using a CE 5980 GC coupled to an HP Finnigan $8222 \mathrm{MS}$ held at $80^{\circ} \mathrm{C}$ for three minutes and raised to $310^{\circ} \mathrm{C}$ at $3^{\circ} \mathrm{C}$ min $-1,1 \mu \mathrm{l}$ of the sample was punctured through the inlet using an automatic sampling device at final temperature for 20 minutes with hydrogen as the carrier gas with a flow rate of $1 \mathrm{ml} / \mathrm{min}$, pressure of 50 $\mathrm{kPa}$. Representative peaks matching the available compounds 
were generated by Agilent ChemStation software.

\section{Results}

Results of various determinations are presented in the Tables 1-5.

\section{Result of Moisture Content Determination}

The result of moisture content determination for the 3 bitumen extracts is presented in the Table 1.

\begin{tabular}{|c|c|}
\hline Extract/Solvent & Moisture content (\%) \\
\hline Diethyl ether (DEE) & 1.3 \\
\hline N-Hexane & 1.0 \\
\hline Methanol & ND \\
\hline
\end{tabular}

Table 1: Result of Moisture Content.

KEY: ND; Not Detected

\section{Result of Nitrogen Content}

The result of nitrogen content for the 3 bitumen extracts is presented in the Table 2 .

\begin{tabular}{|c|c|}
\hline Extract/Solvent & Nitrogen content (\%) \\
\hline Diethyl ether & 0.854 \\
\hline N-Hexane & 0.784 \\
\hline Methanol & 0.084 \\
\hline
\end{tabular}

Table 2: Result of Nitrogen Content

\section{Result of the Total Sulphate Analysis}

The result of total sulphate concentration in the 3 bitumen extractions is presented in Table 3.

\begin{tabular}{|c|c|}
\hline Extract/Solvent & Sulphate content (\%) \\
\hline Diethyl ether & 0.70 \\
\hline N-Hexane & 0.62 \\
\hline Methanol & 0.12 \\
\hline
\end{tabular}

Table 3: Result of Total Sulphate Analysis.

\section{Result of XRF Analysis}

The result of X-ray florescence spectroscopy (XRF) Analysis of the Nitrogen Bitumen Extraction is presented in Table 4.

\begin{tabular}{|c|c|c|c|}
\hline $\mathbf{S} / \mathbf{N}$ & Oxide/Element & IUPAC Name & \% Composition \\
\hline 1 & $\mathrm{Fe}_{2} \mathrm{O}_{3}$ & Iron (III) oxide & 7.33 \\
\hline 2 & $\mathrm{Al}_{2} \mathrm{O}_{3}$ & Aluminum oxide & 1.23 \\
\hline 3 & $\mathrm{SiO}_{2}$ & Silicon dioxide & 3.73 \\
\hline 4 & $\mathrm{SO}_{3}$ & Sulfur trioxide & 13.74 \\
\hline 5 & $\mathrm{CaO}$ & Oxo calcium & 12.34 \\
\hline 6 & $\mathrm{TiO}_{2}$ & Titanium dioxide & 1.14 \\
\hline 7 & $\mathrm{SrO}$ & Strontium oxide & 1.81 \\
\hline 8 & Other Oxides (Trace) Including L.O.I & & 58.68 \\
\hline
\end{tabular}

KEY: L.O.I; Loss on Ignition

Table 4: Result of XRF Analysis.

\section{Result of GC-MS Analysis}

The GC-MS result is presented in Table 5.

\begin{tabular}{|c|c|c|c|c|c|c|c|}
\hline S/N & Dominant Compound & & Area (\%) & & & Quality (\%) & \\
\hline & & NH & DEE & ME & NH & DEE & ME \\
\hline 1 & 9,12 -Octadecadienoic acid & 61.28 & 62.78 & 2.82 & 99 & 97 & 98 \\
\hline 2 & n-Hexadecanoic acid & 7.44 & 6.47 & 6.33 & 98 & 98 & 99 \\
\hline 3 & Linoelaidic acid & - & - & 64.18 & & & 90 \\
\hline 4 & Octadecanoic acid & 11.29 & 11.21 & 10.64 & 99 & 96 & 98 \\
\hline 5 & Methyl 9,12-heptadecadienoate & 2.77 & 3.40 & 2.75 & 93 & 86 & 93 \\
\hline 6 & Butyl 9,12-octadecadienoate & 6.85 & 5.19 & 6.50 & 95 & 95 & 95 \\
\hline 7 & 9,17-Octadecadienoicacid & 4.22 & 4.65 & 3.82 & 97 & 95 & 96 \\
\hline
\end{tabular}

KEY: NH; N-hexane, DEE; Diethyl-ether, ME; Methanol

Table 5: Result of GC-MS Analysis of the Various Bitumen Extracts. 


\section{Journal of Ecology and Natural Resources}

\section{Discussion}

The result of the moisture content determined for the 3 bitumen extracts is presented in Table 1 . The result showed that highest moisture content $(1.3 \%)$ was obtained in the DEE extract followed by N-Hexane (1.0\%) while no moisture content detected in the Methanol extract. The result of the high moisture content in bitumen reported by Read J, Singh PS South African bitumen, $(11.06 \pm 0.11 \%)$ was less than that of Edo state Nigeria $(16.77 \pm 1.47 \%)$. The low value of moisture content showed that the Nigerian bitumen is of good quality and can withstand long storage without decomposing. Accordingly, the least value of moisture obtained in the methanol extract justifies that the methanol was good drying agent and as expected, showed less moisture than the other two extracts. Similar opinions were reported by Speight [15], Spirov and coworkers [16], Liu, et al. [17], Abramov, et al. [18], Odebunmi and George [19] as well as Ohenhen, I [20].

The nitrogen content determination for the 3 bitumen extracts presented in the Table 2 while the total sulphate analysis in Table 3. DEE extract had 0.854 and $0.70 \%$ Nitrogen and total sulphate respectively. $\mathrm{N}-$ Hexane extract had 0.784 and $0.62 \%$ Nitrogen and total sulphate respectively, while Methanol recorded 0.084 and 0.12 Nitrogen and total sulphate composition respectively. Similar result obtained by Carrington S, Akande JM [21,22] reported $0.81 \pm 1.65 \%$ and $0.77 \pm 1.47 \%$ for nitrogen and total sulphate concentrations respectively.

The result of the X-Ray Fluorescence (XRF) analysis of the nitrogen bitumen extraction is presented in Table 4. The results showed the presence of eight major oxide/elements. Trace (Other impurities) had the highest percentage (\%) composition of $58.68 \%$, followed by Sulfur trioxide $\left(\mathrm{SO}_{3}\right)$ with $13.74 \%$, Oxo calcium (CaO) with $12.34 \%$, Iron (III) oxide $\left(\mathrm{Fe}_{2} \mathrm{O}_{3}\right)$ with $7.33 \%$, Silicon dioxide $\left(\mathrm{SiO}_{2}\right)$ with $3.73 \%$, Strontium oxide (SrO) with $1.81 \%$, Aluminium oxide $\left(\mathrm{Al}_{2} \mathrm{O}_{3}\right)$ with $1.23 \%$ and lastly, Titanium dioxide $\left(\mathrm{TiO}_{2}\right)$ had the least with $1.14 \%$. Litrature by Lancaster IM, Souraki Y, Onojake MC, Adebiyi FM, Energy L [23-27] which stated in their study that asbestos rock contains $37.86 \%$ asphalt, $43.28 \%$ carbonate solids, and $18.86 \%$ other impurities. Other impurities could have been solid $\mathrm{SiO}_{2}, \mathrm{CaSO}_{4}, \mathrm{CaS}$, and others.

According to Onoh JK, Adegoke OS, Adedimila AS, Read J, Singh PS, Adegoke OS, Vancleave J [28-35] these solids have very low solubility in water and acid when compared with carbonate solids. This cause other impurities still remain in the asphalt. In the previous study, asbuton rock from Lawele was previously found to contain mineral and asphalt. Asphalt from asbuton rock has high viscocity because the asphaltene content is high. On the average, asbuton rock contains $30.08 \%$ asphalt and $9.92 \%$ mineral. However, The $\mathrm{CaO}$ content decreases with the increase of other oxides present in the limestones. This may be attributed to the leaching of calcium by the solution and subsequent reprecipitation. Change of environment is indicated by the increase of $\mathrm{SiO}_{2}$ content with the influx of terrigenous material [29]. The presence of $\mathrm{Fe}_{2} \mathrm{O}_{3}$ and high $\mathrm{Ca}$ indicates reducing environment and deposition in closed basin. The presence of little amount of phosphate and manganese in the limestone indicates a warm and humid climate during the deposition of carbonate sediments Adedimila AS [30] $\mathrm{Fe}_{2} \mathrm{O}_{3}$ correlates positively with $\mathrm{S}$ and authigenic minerals (pyrite, marcasite, calcite, gypsum).

The use of chemical agents to react with the minerals was found to be much more expensive and difficult to control the product, since certain chemical agents reacted to a particular mineral only, while usually, about $15-20 \%$ of the minerals were not limestone. Besides, some acid compounds chosen were also reactive to the metal equipment used in the process [31-35].

Table 5 presents the GC-MS results of the three extracts in the work. The dominant compounds obtained in all the 3 solvents were about six viz; 9,12-octadecanoic acid, n-Hexadecanoic acid, octadecanoic acid, methyl-9,12heptadecadienoate, butyl-9,12-octadecadienoate as well as 9,17-octadecadienoic acid. Organic compounds, as reported by Ademoroti CMA, AOAC, Yasin G, Adebiyi FM [36-39] are the dominant compounds in the Nigerian bitumen extracts.

Linoelaidic acid appeared only in the ME extract, it is clear that the quality of the compounds is excellent and there is observable relation between the total area percentage of the compounds in the extracts.

The value for 9, 12-octadecadienoic acid is 61.28 and $62.78 \%$ in the $\mathrm{NH}$ and DEE extracts respectively, while insignificant amount (2.82\%) is obtained in the ME extract.

Accordingly, the appearance of almost all the compounds gave best quality in the $\mathrm{NH}$ followed by $\mathrm{ME}$ and DEE. However, methyl9,12-heptadecadienoate ester showed the best appearance (3.40) in the DEE extract while butyl9,12octadecadienoate ester showed best appearance (6.85) in the NH extract.

\section{Conclusion}

Extracts of Nigerian bitumen were used to test-run hypothesis by the ASTM 2007 that the quality of bitumen extracts is not significantly affected by the method of extraction and was observed to be true. The components of Nigerian Bitumen are mixtures, reach in different classes of hydrocarbons hence; the bitumen is a potential tool that can be utilised for energy production. 


\section{References}

1. Meyer RF, Attanasi ED (2010) Natural bitumen and extra-heavy oil. 2010 Survey of Energy Resources, World Energy Council pp: 123-150.

2. Composition \& bitumen properties.

3. Milos CB (2015) Weighing the True Costs. pp: 1-12.

4. Ali MJ, Dhobale SB (2018) A Study on aging Behavior of paving Grade Bitumen using Filler Material.

5. Ebii C (2015) Not All That Glitters: Nigeria's Bitumen Story. pp: 1-3.

6. Sepulveda JE, Miller JD, Oblad AG (1978) Hot water extraction of bitumen from Utah tar sands. Mining Eng 30(9): 1311.

7. Orire E (2009) The Techno-Economics of Bitumen Recovery from Oil and Tar Sands as a 1 Complement to Oil exploration in Nigeria (Doctoral dissertation, NorthWest University).

8. Christina M (2010) Bitumen in Nigeria; Weighing the True Costs of Extraction. Heinrich Boll Foundation Nigeria pp: 1-12.

9. Guma TN, Madakson PB, Yawas DS, Aku SY (2012) Assessment of Physicochemical Properties of some Bitumens from Nigerian Resources. Nigerian Journal of Basic and Applied Science (20)2: 177-181.

10. Francis IN (2016) Prospects of Tarsands in Nigeria Energy Mix. The International Journal of Engineering and Sciences 5(12): 84-89.

11. Adedimila AS (2004) Characterization of Nigeria's Natural Bitumen; Paper Presented at the National Engineering Conference and Annual General Meeting of the Nigerian Society of Engineers, Petroleum Training Institute, 2004, Effurun, Warri, Delta State, Nigeria.

12. Adebiyi FM, Akhigbe GE (2015) Characterization of Paraffinic Hydrocarbon Fraction of Nigerian Bitumen Using Multivariate Analytical Techniques. Journal of Unconventional Oil and Gas Resources 12: 34-44.

13. Subramanian M, Deo MD, Hanson FV (2014) Compositional Analysis of Bitumen and BitumenDerived Products. J Chromatogr Sci 34(1): 20-26.

14. Krebs RD, Walker RD (1971) "Highway Materials," McGraw - Hill Book Co., New York.

15. Speight GJ (1999) Extraction Technologies for national
Bitumen and Heavy Oil. Coal, Oil Shale, Natural Bitumen, Heavy Oil and Peat 2: 1-9.

16. Spirov P, Rudyk S, Tyrovolas A, Jimoh I (2016) The Bitumen Extraction from Nigerian tar Sand using dense Carbondioxide. Chemical engineering Transactions 32: 283-288.

17. Liu Y, Qui Z, Zhong H, Nie Z, Li J, et al. (2019) Bitumen recovery from crude Bitumen Samples from Halfaya Oilfield by Singlr and Composite Solvents-Process, parameters and Mechanisms. Materials 12(17): 2656.

18. Abramov OV, Abramov VO, Myasnikov SK, Mullakaev MS (2009) Extraction of Bitumen, Crude Oil and its Products from Tar Sand and Contaminated sandy Soil Under Effect of Ultrasound. Ultrasonics Sonochemistry 16(3): 408416.

19. Odebunmi EO, George AO (2015) Extraction of Chemical Constituents of Bitumen Using a mixed solvent System. Open Journal of Applied Science 5(8): 485-494.

20. Ohenhen I, Ikiesikimama SS, Olafuyi OA (2016) Effect of Temperature on Nigeria Tar Sand Bitumen Viscosity. In: SPE Nigeria Annual International Conference and Exhibition. Lagos: Society of Petroleum Engineers: 1-7.

21. Carrington S, Langridge J (2015) Viscometer or Rheometer? Making the Decision.

22. Akande JM (2017) Analysis of Steam Injection and insitu Combustion Methods of Mining Agbabu Bitumen in Ondo State, Nigeria. Journal of Engineering and Applied Sciences 2(10): 1493-1496.

23. Lancaster IM (2013) Bitumen \& Bituminous Materials: 1-33.

24. Souraki Y, Ashrafi M, Karimaie H, Torsaeter O (2012) Experimental Analyses of Athabasca Bitumen Properties and Field Scale Numerical Simulation Study of Effective Parameters on SAGD Performance. Energy and Environment Research 2(1): 140-156.

25. Onojake MC, Ndubuka CO (2016) Appraisal of the Bulk Properties of Bitumen Samples from Four Deposits in South West, Nigeria. Petroleum \& Coal 58(4): 407-413.

26. Adebiyi FM, Bello 00, Sonibare JA, Macaulay SRA (2015) Determination of Sara Constituents of Southwestern Nigerian Tars Sands and their Physical Properties. Engineering Journal of the University of Qatar 18: 29-38.

27. Energy L (2017) Heavy Oil. In: Latina American Conference and Exhibition. Mexico: Canadian Heavy Oil Association pp: 1-17. 
28. Onoh JK (1983) The Nigerian Oil Economy. St. Martins Press, NY.

29. Adegoke OS (1980) Geological Guide to Some Nigerian Cretaceous recent Localities, 16th Annual Conf Nig Mining and Geos Soc 27-36.

30. Adedimila AS (1987) Okitipupa Bituminous Sands: New Construction Materials for Flexible Pavements? The Nig Eng 22(3): 1-14.

31. Adedimila AS, Olagoke AA (1990) Basic Engineering Characteristics of Ondo State Bitumen Deposits, Unpub. Report, Dept of Civ Eng Univ of Lagos.

32. Read J, Whiteoak D (2003) The Shell Bitumen Handbook. $5^{\text {th }}$ (Edn.), Hunter RN (Ed.,), Thomas Telford: London.

33. Singh PS, Ray P, Xie Z, Hoang M (2012) Synchrotron saxs to probe cross-linked network of polyamide 'reverse osmosis' and 'nanofiltration' membranes". J Membr Sci 51: 421-422.

34. Adegoke OS, Omotsola ME, Coker JL (1991) The Geology of Nigerian Tar-Sands: Heavy Crude and Tar-Sands Hydrocarbon for the 21st Century. Proceedings of $5^{\text {th }}$ UNITAR International Conference on Heavy Crude and Tar sands: 365-835.

35. Vancleave J (2016) What are rocks?

36. Ademoroti CMA (1996) Standard methods for water and effluents analysis. Ibadan: Foludex Press Ltd 3: 29-118.

37. Association of Official Analytical Chemists (AOAC) (2000) Official Methods of Analysis. 17th (Edn.), Washington: Association of Official Analytical Chemists.

38. Yasin G, Bhanger MI, Ansari TM, Naqvi SMSR, Ashraf M, et al. (2013) Quality and chemistry of crude oils. Journal of Petroleum Technology and Alternative Fuels 4(3): 5363.

39. Adebiyi FM, Omode AA (2007) Organic, Chemical and Elemental Characterization of Components of Nigerian Bituminous Sands Bitumen. Energy Sources, Part A: Recovery, Utilization, and Environmental Effects 29(8): 669-676. 